\title{
DETERMINANTS OF POSTPARTUM DEPRESSION AFTER EARTHQUAKE IN LOMBOK, INDONESIA
}

\author{
Baiq Tuhu Abdiani' ${ }^{1}$, Didik Tamtomo², Hanung Prasetya ${ }^{3)}$ \\ ${ }^{1)}$ Masters Program in Public Health, Universitas Sebelas Maret \\ 2)Faculty of Medicine, Universitas Sebelas Maret \\ ${ }^{3)}$ School of Health Polytechnics, Ministry of Health Surakarta
}

\begin{abstract}
Background: Environmental stressors such as disasters may contribute to an increased the risk of depression within the population affected. Previous studies reported that natural disaster conditions suggest loss of psychosocial resources and it was associated with psychological distress. The purpose of this study was to examine determinants of postpartum depression after earthquake in Lombok, Indonesia.

Subjects and Method: A cross sectional study was conducted at 25 villages in East Lombok, Indonesia, from March to April 2019. A sample of 225 postpartum mothers was selected by stratified random sampling. The dependent variable was postpartum depression. The independent variables were age, parity, income, history of obstetrics, social support, stress coping, health personnel role, and feeling of loss. Data on postpartum depression was measured by Edinburgh postnatal depression scale. The other variables were collected by questionnaire and analyzed by a multiple logistic regression. Results: Age $<20$ or $>35$ years $(b=1.16 ; 95 \% \mathrm{CI}=0.37$ to $1.95 ; \mathrm{p}=0.004)$, parity $<2$ or $>4(\mathrm{~b}=0.83 ; 95 \% \mathrm{CI}=0.05$ to $1.61 ; \mathrm{p}=0.037)$, and high feeling of loss $(\mathrm{b}=0.50 ; 95 \%$ $\mathrm{CI}=0.31$ to $0.69 ; \mathrm{p}<0.001)$ increased the risk of postpartum depression after earthquake. The risk of postpartum depression reduced with high income $(b=-0.03 ; 95 \%$ $\mathrm{CI}=-0.06$ to $0.00 ; \mathrm{p}=0.027)$, and strong social support $(\mathrm{b}=-0.06 ; 95 \% \mathrm{CI}=-0.13$ to $0.00 ; \mathrm{p}=0.087)$, good stress coping $(\mathrm{b}=-0.18 ; 95 \% \mathrm{CI}=-0.25$ to $-0.10 ; \mathrm{p}<0.001)$, and strong health personnel role $(b=-1.10 ; 95 \% \mathrm{CI}=-1.93$ to $-0.27 ; \mathrm{p}=0.009)$.

Conclusion: Age $<20$ or $>35$ years, parity, and high feeling of loss increase the risk of postpartum depression after earthquake. The risk of postpartum depression reduces with high income, and strong social support, good stress coping, and strong health personnel role.
\end{abstract}

Keywords: postpartum depression, earthquake, stress coping, feeling of loss

\section{Correspondence:}

Baiq Tuhu Abdiani. Masters Program in Public Health, Universitas Sebelas Maret. Jl. Ir. Sutami 36A, Surakarta 57126, Central Java. Email: tuhuabdiani8@gmail.com Mobile: 081999546500. 